\title{
TELAAH KRITIS BAHAN AJAR BAHASA ARAB ANAK USIA DINI PERSPEKTIF TEORI BELAJAR HUMANISTIK
}

\author{
CARL R. ROGERS
}

\author{
Oleh: Nurhapsari Pradnya Paramita \\ Dosen STAIMS Yogyakarta
}

\begin{abstract}
The Arabic language is a gateway to science, especially the Islamic sciences. This awareness drives the Islamic educational institutions to teach Islamic education early on. The Arabic language has been introduced since early childhood. Learning the Arabic language in early childhood starting from simple vocabulary to introduce complete sentences.

The purpose of this research is to study was used to determine whether the model of learning the Arabic language to early childhood that are relevant to the stage of development of language acquisition in children through the perspective of Humanistic Psychology of Carl Rogers. This research is the kind of research the documents because the data examined is learning Arabic for early childhood.

Arabic learning materials for early childhood from which research E-book whom Haza and Hazihi (learn Arabic for early childhood), Independent creative activity Book, learning Arabic Guide CD for kindergarten teacher. According to the perspective of Carl Rogers, the third of this material can be used as an ingredient in Arabic language learning activities since children aged less than one year, only. According to Carl Rogers, humans have tend to learn. Since the birth of the child has had a tendency to learn. Teaching Arabic early allows children to achieve the highest level of fluency.
\end{abstract}

\begin{abstract}
Abstrak
Bahasa Arab adalah pintu gerbang untuk ilmu pengetahuan, terutama ilmu-ilmu Islam. Kesadaran ini mendorong lembaga pendidikan Islam untuk mengajarkan pendidikan Islam sejak dini. Bahasa Arab telah diperkenalkan sejak anak usia dini. Belajar bahasa Arab pada anak usia dini mulai dari kosakata sederhana untuk memperkenalkan kalimat lengkap.

Tujuan dari penelitian ini adalah untuk studi yang digunakan untuk menentukan apakah model pembelajaran bahasa Arab untuk anak usia dini yang relevan dengan tahap pengembangan penguasaan bahasa pada anak-anak melalui perspektif Psikologi Humanistik Carl Rogers. Penelitian ini adalah jenis penelitian dokumen karena data diperiksa adalah belajar bahasa Arab untuk anak usia dini.

bahan pembelajaran bahasa Arab untuk anak usia dini yang penelitian E-book yang Haza dan Hazihi (belajar bahasa Arab untuk anak usia dini), aktivitas kreatif Independent Book, belajar bahasa Arab Gratis CD untuk guru TK. Menurut perspektif Carl Rogers, ketiga bahan ini dapat digunakan sebagai bahan dalam kegiatan pembelajaran bahasa Arab sejak anak berusia kurang dari satu tahun, hanya. Menurut Carl Rogers, manusia harus cenderung untuk belajar. Sejak kelahiran anak memiliki kecenderungan untuk belajar. Pengajaran Bahasa Arab awal memungkinkan anak-anak untuk mencapai tingkat tertinggi kefasihan.
\end{abstract}

\section{A. Latar Belakang}

Bahasa Arab merupakan pintu gerbang ilmu pengetahuan. Kesadaran ini menggerakkan lembaga Pendidikan Islam untuk mengajarkan pendidikan Islam sejak dini. Pembelajaran Bahasa Arab pada anak usia dini mulai dari mengenalkan kosakata sederhana hingga kalimat lengkap. Tujuan mempelajari bahasa Arab pada usia dini dimaksudkan sebagai tahap perkenalan agar 
dikemudian hari anak memiliki motivasi tinggi dalam mempelajari bahasa Arab. Usia dini merupakan golden age atau usia emas dimana setiap ilmu yang diberikan dengan mudah diserap. Sebagaimana kata pepatah "Mendidik anak pada usia dini seperti mengukir pada batu" , artinya membimbing anak semenjak kecil akan membekas selamanya.

Sebagaimana pendapat Montessori mengenai perkembangan anak; yaitu anak usia 0-3 tahun memiliki kepekaan sensoris dan daya pikir yang sudah mulai dapat "menyerap" pengalaman-pengalaman melalui sensori. Usia 0.5-3 tahun, anak mulai memiliki kepekaan bahasa sangat tepat untuk mengembangkan bahasanya (berbicara, bercakap-cakap). Usia 2-4 tahun, gerakan otot mulai dapat dikoordinasikan dengan baik, untuk berjalan maupun untuk banyak bergerak yang semi rutin dan rutin, berminat pada benda-benda kecil, dan mulai menyadari adanya urutan waktu (pagi, siang, sore dan malam). Usia 3-6 tahun, terjadilah kepekaan untuk peneguhan sensoris, semakin memiliki kepekaan inderawi. Khusus, pada usia sekitar 4 tahun, anak mulai memiliki kepekaan menulis sehingga pada usia 4-6 tahun, anak memiliki kepekaan yang bagus untuk membaca. ${ }^{1}$

Namun seringkali lembaga pendidikan maupun guru mengabaikan konsep perkembangan tersebut. Anak usia dini diberikan beban belajar melebihi kapasitas anak. Anak usia dini yang diberi beban belajar yang berat, cenderung cepat bosan dan mengalami kejenuhan. Kejenuhan yang mereka alami saat kanak-kanak akan berimplikasi negatif ketika mereka dewasa.

Perkembangan yang diperlukan pada masa usia dini adalah perkembangan motorik, baik motorik kasar maupun halus. Perkembangan motorik anak sangat berpengaruh pada kesehatan, perkembangan sosial-emosional anak dan perkembangan kognitif. Pertumbuhan dan perkembangan fisik/ motorik anak akan mempengaruhi cara memandang dirinya sendiri dan orang lain. Oleh karena itu kegiatan pembelajaran pada anak usia dini harus mempertimbangkan kegiatan pengembangan fisik motorik.

Pengembangan pembelajaran tidak terlepas dari pengaruh psikologi, khususnya teori belajar. Pembelajaran yang tepat untuk saat ini ialah konsep pembelajaran memanusiakan manusia, baik dari segi perncanaan, materi ajar, proses, maupun evaluasi. Mempertimbangkan latar belakang masalah diatas penulis menganggap perlu adanya kajian mengenai konsep pembelajaran Bahasa Arab pada anak usia dini. Penelitian ini bermaksud untuk menelaah materi pembelajaran bahasa Arab bagi anak usia dini di Indonesia menggunakan Peraturan Menteri Pendidikan Nasional Republik Indonesia nomor 58 tahun 2009. Selain itu, peneliti akan menelaah materi pembelajaran bahasa Arab bagi anak usia dini melalui perspektif ahli teori humanistik Carl Rogers.

\section{B. Rumusan Masalah}


1. Bagaimanakah konten bahan ajar Bahasa Arab Bagi Anak Usia Dini di Indonesia ?

2. Bagaimana bahan ajar Pembelajaran Bahasa Arab Bagi Anak Usia Dini di Indonesia menurut perspektif teori belajar humanistik Carl Rogers?

\section{Kajian Pustaka}

Berdasarkan penelusuran penulis terhadap beberapa karya hasil penelitian sebelumnya yang membahas pembelajaran bahasa Arab maupun bahasa asing untuk anak usia dini, diantaranya :

1. Penelitian yang dilakukan saudara Zukhaira Zukhaira dalam jurnal Abdimas dengan judul "Pengenalan Bahasa Arab melalui nyanyian pada Anak Usia Prasekolah di TK Islam "Mutiara Hati" yang dilakukan pada tahun 2010 di Patemon Kecamatan Gunungpati Semarang. Proses penelitian dilakukan dengan cara praktik mengajarkan bahasa Arab menggunakan metode bernyanyi sambil bermain, bernyanyi dengan gerakan dan bernyanyi dengan menggunakan media pembelajaran. Penelitian ini menyimpulkan bahwa siswa pra sekolah mudah menghafalkan kosakata bahasa Arab dengan metode gerak dan lagu, selain itu minat siswa tampak saat menyanyikan lagu-lagu tersebut karena lagu yang diajarkan memiliki syair yang pendek.

2. Penelitian yang dilakukan Kathleen Marcos dengan judul Second Language Learning: Everyone Can Benefit di virginia tahun 1990 yang menyimpulkan bahwa pembelajaran bahasa kedua memberi banyak manfaat bagi siswa diantaranya, meningkatnya kemampuan komunikasi, perkembangan kognitif, kesadaran budaya dan peluang kerja.

3. Penelitian yang dilakukan saudara Amrie Poerbha Yogya Sayektie dengan judul "Pengenalan Bahasa Arab Melalui Metode Gerak Dan Lagu Di Taman Kanak-Kanak Islam Pdhi Jogoragan Banguntapan Bantul Yogyakarta Tahun Pelajaran 2008-2009” yang dilakukan pada tahun 2009 di Jogoragan Banguntapan Bantul. Proses penelitian dilakukan menggunakan metode observasi, wawancara, dan dokumentasi dengan sumber data guruguru TK. Penelitian ini menyimpulkan bahwa metode gerak dan lagu memiliki beberapa kelebihan dan kekurangan. Kelebihan kegiatan gerak dan lagu diantaranya : memberikan suasana senang, membantu menguatkan daya ingat anak, dengan gerak anak dapat mengekspresikan perasaannya dan menghilangakan kebosanan. Sedangkan kekurangan dari metode gerak dan lagu dapat di lihat dari dua segi, segi linguistik dan segi non lingustik. Segi lingusitik antara lain : anak-anak merasa asing dengan bahasa Arab, dari segi perbedaan tulisan, dan perbedaan atau persamaan bunyi huruf Arab. Segi non linguistik antara lain: anak-anak berlebihan dalam bergerak, belum ada guru khusus bahasa Arab, kurikulum yang belum baku, dan kurangnya referensi lagu bahasa Arab. 
Setelah peneliti melakukan pengamatan terhadap penelitian terdahulu, terdapat perbedaan dan kesamaan. Persamaan penelitian ini dengan penelitian saudara zukhaira pada subjek penelitian yaitu pembelajaran bahasa Arab untuk anak usia dini, perbedaanya saudara zukhaira meneliti tentang metode pembelajaran bahasa Arab sedang tesis ini akan menganalisa materi pembelajaran bahasa Arab.

Persamaan dengan penelitian yang dilakukan Kathleen Marcos yaitu sama-sama meneliti pembelajaran bahasa kedua/asing bagi anak-anak, perbedaannya terletak pada objek kajian penelitian ini menelaah materi pembelajaran bahasa Arab sedangkan penelitian Kathleen Marcos meneliti urgensi dan manfaat pembelajaran bahasa kedua bagi anak-anak.

Persamaan dengan penelitian yang dilakukan Amrie Poerbha Yogya Sayektie yaitu sama-sama meneliti pembelajaran bahasa Arab untuk anak usia dini, sedangkan perbedaanya yaitu; penelitian saudara Amrie meneliti tentang metode pembelajaran bahasa Arab sedang tesis ini akan menganalisa materi pembelajaran bahasa Arab.

\section{Kerangka Teoritik}

\section{Penguasaan berbahasa}

Pada hakikatnya, penguasaan berbahasa anak atau seseorang (pembelajar) bahasa terjadi karena pemerolehan atau pembelajaran. ${ }^{2}$ Para pakar sepakat terdapat dua langkah dalam menguasai bahasa. Pertama, penguasaan bahasa yang dilakukan secara tidak disadari dan bersifat informasi. Kedua, penguasaan bahasa yang dilakukan secara disadari dan bersifat formal. Penguasaan dengan cara pertama disebut pemerolehan, sedangkan cara kedua disebut pembelajaran. ${ }^{3}$

Pembelajaran bahasa biasa dilaksanakan dalam kelas dengan komponen pengajar, pembelajar, materi, tujuan, kegiatan belajar mengajar, dan evaluasi. Dalam kegiatan belajar, pembelajar berusaha menguasai bahasa target seperti bahasa penutur asli. Pembelajar yang berhasil secara ideal dapat menguasai bahasa target menyamai kecakapan penutur asli orang dewasa.

\section{Kemahiran Berbahasa}

\section{a. Pengertian Kemahiran Berbahasa}

Secara bahasa kemahiran sama dengan kesanggupan atau kecakapan. Sedangkan kemahirann berbahasa adalah kemampuan individu untuk mendengarkan ujaran yang disampaikan oleh lawan bicara, berbicara dengan lawan bicara, membaca pesan-pesan

${ }^{2}$ Carol Seefeldt, Pendidikan Anak Usia Dini (Jakarta: Indeks, 2008) Hlm. 17 
yang disampaikan dalam bentuk tulis, dan menulis pesan-pesan baik secara lisan maupun tulisan.

\section{b. Jenis-jenis Kemahiran Berbahasa}

1) Kemahiran Mendengar (Istima')

Istima' mempunyai peran penting dalam kehidupan, karena kemampuan mendengar (istima') merupakan sarana pertama yang digunakan dalam berhubungan dengan manusia. Melalui mendengar, kita mengenal mufradat, bentuk-bentuk jumlah dan taraakib. Ahmad Fuad Effendy mengungkapkan beberapa tahapan-tahapan latihan menyimak, yaitu sebagai berikut: ${ }^{4}$

a) Latihan pengenalan (identifikasi)

Pada tahap ini, bertujuan agar dapat mengidentifikasi bunyi-bunyi bahasa secara tepat. Dalam menyajikan pelajaran, bisa langsung oleh guru secara lisan, maupun melalui rekaman.

b) Latihan mendengarkan dan menirukan

Dalam tahapan pemula, siswa dilatih untuk mendengarkan dan menirukan ujaran guru. Oleh karena itu, harus dipilihkan bahan yang pendek, mungkin berupa percakapan sehari-hari atau ungkapan-ungkapan sederhana yang tidak terlalu kompleks.

c) Latihan mendengarkan dan memahami

Pada tahap ini, mendengarkan bertujuan agar siswa mampu memahami bentuk dan makna dari apa yang telah didengar. Dalam hubungannya dengan latihan mendengarkan untuk pemahaman ini, ada beberapa teknik yang perlu diperhatikan, yaitu:

- Latihan melihat dan mendengar.

- Latihan membaca dan mendengar.

- Latihan mendengar dan memperagakan.

- Latihan mendengar dan memahami.

2) Kemahiran Berbicara (kalam)

Pelajaran bahasa pada umumnya ditujukan pada ketrampilan berbicara atau ketrampilan menggunakan bahasa lisan. Kemahiran berbicara merupakan kemampuan berkomunikasi secara langsung dalam bentuk percakapan atau dialog. Latihan-latihan percakapan (diskusi, dialog) serta latihan membuat laporan lisan, dapat juga menambah ketrampilan berbicara.

4 Ahmad Fuad Effendy, Metodologi Pengajaran Bahasa Arab (Malang: Misykat, Cet.III, 2005), hlm. 103-206. 
Persoalan yang tidak kurang pentingnya agar siswa trampil berbicara, adalah latihan-latihan keberanian berbicara. Selain bergantung pada sikap guru, tugas-tugas mengadakan komunikasi dengan orang lain (selain guru kelas) dapat juga menimbulkan keberanian berbicara bagi siswa-siswa pemula, persoalannya keberanian (berbicara) perlu mendapat latihan-latihan seperlunya. Dengan demikian latihan berbicara harus terlebih dahulu didasari oleh:

- Kemampuan mendengarkan

- Kemampuan mengucapkan

- Penguasaan (relatif) kosa kata yang diungkapkan yang memungkinkan siswa dapat mengkomunikasi-kan maksud / fikirannya.

Adapun tahapan-tahapan latihan berbicara adalah sebagai berikut: Pada tahaptahap permulaan, latihan berbicara dapat dikatakan serupa dengan latihan menyimak. Sebagaimana telah dikemukakan sebelum-nya, dalam latihan menyimak ada tahap mendengarkan dan menirukan. Latihan mendengarkan dan menirukan ini merupakan gabungan antara latihan dasar untuk kemahiran menyimak dan kemahiran berbicara. Namun harus disadari bahwa tujuan akhir dari keduanya berbeda. Tujuan akhir latihan menyimak adalah kemampuan memahami apa yang disimak. Sedangkan tujuan akhir latihan pengucapan adalah kemampuan ekspresi (ta'bir), yaitu menggunakan ide/pikiran/ pesan kepada orang lain. Keduanya merupakan syarat mutlak bagi sebuah komunikasi lisan yang efektif secara timbalbalik. Berikut ini ada beberapa model latihan berbicara :

a) Latihan asosiasi dan identifikasi

Latihan ini terutama dimaksud untuk melatih spontanitas siswa dan kecepatannya dalam mengindentifikasi dan mengasosiasikan makna ujaran yang didengarnya.

b) Latihan pola kalimat (pattern practice)

Pada pembahasan mengenai teknik pengajaran qawa'id telah diuraikan berbagai macam latihan, secara garis besar dapat dibedakan menjadi 3 macam yaitu, latihan mekanis, latihan bermakna, latihan komunikatif. Semua atau sebagian jenis latihan ini ketika dipraktikkan secara lisan juga merupakan bentuk permulaan dari latihan percakapan. Porsi latihan-latihan mekanis harus dibatasi agar siswa dapat segera di bawa ke latihan-latihan semi komunikatif dan latihan-latihan komunikatif yang sebenarnya.

c) Latihan percakapan 
Latihan percakapan ini terutama mengambil topik tentang kehidupan sehari-hari atau kegiatan-kegiatan yang dekat dengan kehidupan siswa.

d) Bercerita

Berbicara mungkin salah satu hal yang menyenangkan. Tapi bagi yang mendapat tugas bercerita, kadangkala merupakan siksaan karena tidak punya gambaran apa yang akan diceritakan. Oleh karena itu guru hendaknya membantu siswa dalam menemukan topik cerita.

e) Diskusi

Hendaknya dalam pemilihan topik diskusi dipertimbangkan hal-hal sebagai berikut:

- Disesuaikan dengan kemampuan siswa.

- Disesuaikan dengan minat dan selera siswa.

- Topik hendaknya bersifat umum dan popular.

- Dalam menentukan topik, sebaiknya siswa diajak serta untuk

- merangsang keterlibatan mereka dalam kegiatan berbicara.

f) Wawancara

g) Drama

h) Berpidato

3) Kemahiran Membaca (qira'ah)

Kemahiran mengucapkan bahasa dengan melihat atau memperhatikan gambar dapat disebut kemahiran berbicara dengan membaca gambar. Kemampuan ini dapat juga disebut kemampuan menafsirkan atau mengucapkan "bahasa" yang tersirat dalam gambar. Sebelum siswa-siswa dapat membaca (mengucapkan huruf, bunyi, atau lambang bahasa) lebih dahulu siswa-siswa mengenal huruf. Kemampuan pengenalan huruf dapat diperlakukan dengan cara melihat dan memperkirakan guru menulis. Yang dimaksud dengan "dapat membaca" adalah dapat mengucapkan lambang-lambang bahasa dengan dengan pelan latihan membaca menggunakan kartu-kartu kalimat yang dibawa pulang. Kemampuan membaca dalam arti mengerti atau memahami isi bacaan, dapat dilakukan dengan latihan-latihan membaca seberapa kalimat yang sertai gambar (pengalaman siswa). ${ }^{5}$

4) Kemampuan Menulis (kitabah)

Menulis merupakan suatu keterampilan berbahasa yang dipergunakan untuk berkomunikasi secara tidak langsung atau tidak secara tatap muka dengan orang

5 A.S. Broto, Pengajaran Bahasa Indonesia Sebagai Bahasa Kedua di Sekolah DasarBerdasarkan Pendekatan Linguistik Konstransitif (Jakarta: Bulan Bintang, 2000), hlm. 141-143. 
lain. Seperti halnya membaca, kemahiran menulis mempunyai dua aspek, tetapi dalam bentuk yang berbeda. Pertama, kemahiran membentuk huruf dan menguasai ejaan. Kedua, kemahiran melahirkan fikiran dan perasaan dengan tulisan.

Menurut Ahmad Fuad Effendy, beberapa tahapan latihan menulis adalah sebagai berikut ${ }^{6}$ :

a) Mencontoh

1) Siswa belajar dan melatih diri menulis dengan cepat sesuai dengan contoh.

2) Siswa belajar mengeja dengan benar

3) Murid berlatih menggunakan bahasa Arab yang benar.

b) Reproduksi

Adalah menulis berdasarkan apa yang telah dipelajari secara lisan. Dalam tahap ke dua ini siswa sudah mulai dilatih menulis tanpa ada model. Model lisan tetap ada dan harus model yang benar-benar baik.

c) Imlak

Ada dua macam imlak

(1) Imlak yang dipersiapkan sebelumnya. Siswa diberitahu sebelumnya materi/teks yang akan diimlakan.

(2) Imlak yang tidak dipersiapkan sebelumnya. Siswa tidak diberitahu sebelumnya materi/teks yang akan diimlakan. Sebelum penyajian, guru sebaiknya membacakan secara lengkap, kemudian menuliskan beberapa kata sulit di papan tulis dan diterangkan maknanya.

d) Rekombinasi dan transformasi

Rekombinasi adalah latihan menggabungkan kalimat-kalimat yang mulanya transformasi adalah latihan mengubah bentuk kalimat, dari kalimat positif menjadi kalimat negatif,

\section{E. Faktor yang mempengaruhi Pembelajaran Bahasa}

a. Hipotesis Periode Kritis

Periode kritis adalah masa-masa di mana otak seorang manusia sangatlah efektif untuk menerima sesuatu, dan masa tersebut terjadwal secara biologis dan alamiah. Menurut Lenneberg masa emas anak belajar bahasa ialah usia 2-12 tahun. ${ }^{7}$ Suatu bahasa yang datang pada saat periode kritis akan lebih mudah dicerna oleh seseorang dibandingkan bahasa yang datang sesudah periode ini. Hipotesis periode

${ }^{6}$ Fuad, Metodologi.....hal. 138

${ }^{7}$ Soenjono Dardjowidjojo,Psikolinguistik: Pengantar Pemahaman Bahasa Manusia (Jakarta: Yayasan Obor Indonesia, 2010), Hlm. 
kritis mengasumsikan bahwa terdapat hubungan antara pertumbuhan biologis manusia dengan tingkat pemerolehan bahasa.

Kemampuan anak mempelajari bahasa setelah usia pubertas semakin merosot. Karena ketika anak mulai memasuki masa puber, hemisfer kiri dan hemisfer kanan otak mulai mengembangkan fungsinya masing-masing. ${ }^{8}$ Berbagai fungsi otak terposisikan menjadi hemisfer kanan dan hemisfer kiri. Dimana hemisfer kiri diasosiasikan denga pikiran logis, analitis dengan informasi matematis dan pemrosesan linear. Otak kanan menangkap dan mengingat citra visual, rabaan, dan auditoris lebih efisien dalam pemrosesan informasi holistik, integratif dan emosional.

Lebih lanjut Lenneberg menyatakan bahwa bahasa yang optimal hanya dapat dialami oleh anak-anak ketika otak belum terbagi menjadi dua sisi dan kelenturan otak (plasticity) masih tinggi. Dengan kata lain, sebelum masa pubertas anak-anak belajar bahasa menggunakan kedua sisi otak, sehingga seorang anak akan lebih mudah menguasai bahasa asing dibanding dengan orang dewasa.

Anak-anak akan lebih mudah mempelajari bahasa asing pada lingkungan yang alamiah. Pada lingkungan bahasa tersebut biasa digunakan kemungkinan besar akan memiliki kemampuan menggunakan bahasa, terutama bahasa lisan, mendekati atau sama seperti penutur asli. Orang dewasa mungkin pada awalnya memperlihatkan perkembangan yang lebih cepat, tetapi pada tahap-tahap selanjutnya anak-anak akan mampu melewati kecepatan pemerolehan yang ditunjukkan orang dewasa.

Thomas Scovel menunjukkan bahwa plastisitas otak sebelum akhil balik memungkinan anak-anak menguasai tak hanya bahasa pertama mereka tetapi juga bahasa kedua, dan hal itu mungkin merupakan pencapaian tertinggi lateralisasi sehingga sulit bagi orang dewasa untuk mendapatkan kembali kefasihan bahasa kedua / asing. ${ }^{9}$ Sebagaimana pendapat Scoevel tersebut dapat dikatakan bahwa anak yang mempelajari bahasa kedua/ bahasa asing mampu memiliki kefasihan berbahasa layaknya penutur asli. Kefasihan tersebut akan semakin baik apabila didukung dengan pengajar dari pemilik bahasa asal.

Kemampuan bahasa yang beragam akan membantu saat anak dewasa. Selain meningkatkan kecerdasan otak, mereka akan menjadi pribadi yang fleksibel. Dengan kemampuan berbahasa yang beraneka ragam akan mudah bagi anak-anak untuk belajar lebih banyak dari berbagai sumber bahasa. Sehingga rasa percaya diri dan kemampuan bersosialisasi mereka akan semakin meningkat.

\section{b. Lingkungan}

\footnotetext{
${ }^{8}$ Arifuddin, Neuro Psikolinguistik, (Jakarta: Raja Grafindo, 2010), Hlm. 139

${ }^{9}$ Douglas Brown, Prinsip Pembelajaran dan Pengajaran Bahasa (Jakarta: Pearson Education, 2008), Hlm. 63
} 
Lingkungan menjadi sesuatu yang urgen dalam tahap tumbuh kembang anak, termasuk masalah bahasa. Sebagaimana pendapat Chomsky, bahwa didalam otak seorang anak terdapat alat kebahasaan yang biasa disebut LAD (language acquisition device). Meski demikian peran lingkungan tetap penting dalam pemerolehan maupun pembelajaran bahasa. Bahasa yang berkembang pada seorang anak bukanlah bahasa darimana dia berasal. Namun bahasa dimana tempat bahasa tempat anak tersebut dibesarkan.

\section{F. TEORI HUMANISTIK CARL ROGERS}

Rogers mengkarakterisir guru sebagai seseorang yang mengajar dan memberi informasi, atau seseorang yang menciptakan situasi belajar untuk mendorong timbulnya respon yang benar. Lebih dari itu guru sebagai seseorang yang menyediakan kondisi yang memungkinkan siswa menemukan dan membantu pengalaman belajar yang bersifat kognitif.

Rogers menggambarkan dua tipe dasar tentang belajar, yaitu belajar kognitif dan pengalaman belajar. Belajar kognitif menunjuk kepada jenis-jenis proses assosiasi yang dilambangkan semua teori psikologi belajar tradisional ,termasuk beberapa aspek dari teori kognitif. Sedangkan pengalaman belajar secara manusiawi sangat berarti dan secara emosional relevan dengan teori kognitif.

Rogers menekankan bahwa pengalaman yang paling utama adalah pengalaman yang bersifat afektif, yaitu keterlibatan keseluruhan emosional dalam proses belajar. Keterlibatan siswa yang demikian akan timbul apabila, pendidik membantu siswa untuk mengalami iklim emosional yang memberikan kebebasan belajar. ${ }^{10}$ Beberapa asumsi rogers terkait dengan pengalaman belajar :

a. Manusia memiliki kecenderungan alamiah untuk berkeinginan belajar.

b. Praktek pendidikan tradisional bercirikan bahwa siswa mempelajari apa saja yang dikemukakan gurunya.

c. Penyusunan bahan/ mata pelajaran seharusnya diganti dengan pengalamanpengalaman yang memungkinkan siswa untuk menyatukan informasi dan gagasan baru sebagai bagian dari dirinya.

d. Belajar yang bermanfaat dalam dunia modern adalah proses belajar yang bersifat terbuka yang berkelanjutan terhadap pengalaman dan penggabungan terhadap dirinya.

e. Belajar yang optimal akan terjadi jika siswa berpartisipasi dan bertanggung jawab dalam proses belajar. 
f. Pengalaman belajar akan membantu belajar kreatif, jika terdapat "self critism" dan "self-evaluation" merupakan hal yang kedua.

g. Pengalaman belajar sebagai tujuan pendidikan dapat diperoleh apabila siswa dilibatkan dalam pengalaman belajar. keterlibatan menuntut siswa berpartisipasi dalam membuat keputusan sepanjang proses belajar tersebut.

\section{BAHAN AJAR BAHASA ARAB BAGI ANAK USIA DINI MENURUT CARL ROGERS}

Menurut Carl Rogers, manusia memiliki kecenderunngan untuk belajar. Seorang anak telah memiliki kecenderungan untuk belajar sejak lahir. Demikian pula dalam pembelajaran bahasa, anak mulai mengenal pembelajaran bahasa sejak lahir. Bahasa Arab, sebagai salah satu bahasa asing bagi masyarakat Indonesia dapat pula diajarkan sejak usia anak 0 bulan.

Anak lebih mudah mempelajari bahasa asing pada lingkungan yang alamiah. Pada lingkungan bahasa Arab biasa digunakan kemungkinan besar akan memiliki kemampuan menggunakan bahasa, terutama bahasa lisan, mendekati atau sama seperti penutur asli. Lembaga pendidikan di Indonesia memiliki Siswa paling kecil pada usia antara 6 atau 8 bulan. Pengenalan bahasa Arab dapat dikenalkan semenjak anak usia tersebut, dengan metode yang sesuai dengan tahapan usia anak. Tahap perkebangan belajar dan kemampuan anak sesuai dengan tahap perkembangan Jean Piaget. Tahap perkembangan menurut Jean Piaget :

1. Periode sensorimotor (usia 0-2 tahun)

Anak yang berada pada tahap ini, pengalaman diperoleh melalui fisik (gerakan anggota tubuh) dan sensori (koordinasi alat indra). Pada mulanya pengalaman itu bersatu dengan dirinya, ini berarti bahwa suatu objek itu ada bila ada pada penglihatannya.

Objek mulai terpisah dari dirinya dan bersamaan dengan itu konsep objek dalam struktur kognitifnya pun mulai dikatakan matang. Ia mulai mampu untuk melambungkan objek fisik ke dalam simbol-simbol, misalnya mulai bisa berbicara meniru suara kendaraan, suara binatang, dll.

2. Periode praoperasional (usia $2-7$ tahun)

Tahap ini adalah tahap persiapan untuk pengorganisasian operasi konkrit. Pada tahap ini pemikiran anak lebih banyak berdasarkan pada pengalaman konkrit daripada pemikiran logis, sehingga jika ia melihat objek-objek yang kelihatannya berbeda, maka ia mengatakannya berbeda.

3. Periode operasional konkrit (usia 7-11 tahun) 
Pada umumnya anak-anak pada tahap ini telah memahami operasi logis dengan bantuan benda benda konkrit. Kemampuan ini terwujud dalam memahami konsep kekekalan, kemampuan untuk mengklasifikasikan dan serasi, mampu memandang suatu objek dari sudut pandang yang berbeda secara objektif.

4. Periode operasional formal (usia 11 tahun sampai dewasa)

Anak pada tahap ini sudah mampu melakukan penalaran dengan menggunakan hal-hal yang abstrak dan menggunakan logika. Penggunaan benda-benda konkret tidak diperlukan lagi. Anak mampu bernalar tanpa harus berhadapan dengan dengan objek atau peristiwa berlangsung. Penalaran terjadi dalam struktur kognitifnya telah mampu hanya dengan menggunakan simbolsimbol, ide-ide, abstraksi dan generalisasi.

Pembentukan situasi belajar bagi anak terjadi apabila anak dilibatkan secara afektif dengan cara membentuk lingkungan belajar serta adanya bahan belajar yang kreatif dan menarik perhatian anak. Peneliti akan sedikit mengulas materi/ bahan pembelajaran yang sesuai dengan teori humanistik yang diusung Carl Rogers, yaitu :

1. Bahan ajar seharusnya berisi pengalaman-pengalaman

Materi ajar seharusnya berisi pengalaman-pengalaman yang memungkinkan siswa untuk menyatukan informasi dan gagasan baru sebagai bagian dari dirinya.Materi ajar bahasa Arab sudah sepatutnya mengakomodir empat kemahiran berbahasa. materi yang akan diajarkan diharapkan dpat memberikan pengalaman dalam setiap kemahiran, sehingga sisa dapat menyatukan informasi dan mendapat gagasangagasan baru.

2. Materi pelajaran berisi kegiatan-kegiatan yang membuat siswa aktif berpartisipasi Materi ajar bahasa Arab berisi keterampilan-keteramilan yng membat siswa aktif berpartisipasi sesuai dengan tahapa usia anak.

3. Terdapat "self critism" dan "self-evaluation"

Bahan ajar yang baik menyediakan ruang evaluasi diri, untuk mengukur keterampilan dan keterampilan siswa.

4. Bahan atau materi ajar bahasa arab memberi kesempatan siswa membuat keputusan dalam belajar

Materi ajar yang disiapkan memberikan kesempatan seluas-luasnya kepada siswa untuk memilih dan menentukan aktivitas pembelajaran serta melibatkan siswa dalam membuat keputusan-keputusan penting dalam pembelajaran. 


\section{G. Metode Penelitian}

Pada dasarnya penelitian ini adalah penelitian literatur atau studi kepustakaan. Maka penulis menggunakan metode penelitian kualitatif deskriptif.

1. Jenis penelitian

Penelitian ini merupakan jenis penelitian dokumen karena data yang diteliti merupakan model pembelajaran bahasa arab untuk anak usia dini. Penelitian ini digunakan untuk mengetahui apakah model pembelajaran bahasa Arab untuk anak usia dini tersebut relevan dengan tahap perkembangan pemerolehan bahasa pada anak melalui perspektif Psikologi humanistik Carl Rogers.

2. Teknik Pengumpulan Data

Data primer dalam penelitian ini penulis ambil dari :

a. E-book Haẓa dan Hazihi (Belajar bahasa Arab untuk anak usia dini)

b. Buku Kegiatan Kreatif Mandiri

c. CD panduan pembelajaran bahasa Arab untuk guru TK

Adapun data sekunder penulis menggunakan buku-buku yang relevan dengan pembahasan penelitian.

3. Analisa Data

Analisa data dalam penelitian ini menggunakan pendekatan kualitif deskriptif. Dalam menganalisa data, menggunakan pendekatan psikologi, yaitu psikologi humanistik menurut perspektif Carl Rogers.

\section{H. Hasil Penelitian}

1. KONTEN MATERI AJAR BAHASA ARAB ANAK USIA DINI

a. E-book Haza

E-book haza berisi 32 halaman, berisi pengenalan kata tunjuk dekat dan beberapa kosakata sederhana. Buku haza ditujukan bagi anak usia 5-7 tahun. Buku kecil ini bermasud mengenalkan isim isyarah haza, berikut beberapa kosakata baru yang disertai gambar untuk memudahkan anak-anak mengenalinya. Setiap materi pembelajaran disertai latihan menulis dengan cara menebalkan kata-kata yang sedang dipelajari. E-book Haza juga dilengkapi beberapa dengan pelajaran penggunaan kata tanya dan beberapa latihan.

b. E-book Haẓihi

E-book Hazihi sama dengan E-book haza berisi 32 halaman. E-book Hazihi memuat beberapa kata berjenis muannats yang berakhiran ta' marbuthoh, isim isyarah Hazihi. Dalam buku ini terdapat pula latihan pengenal kata dibagian akhir buku dengan harapan anak dapat membaca meski tanpa disertai tanda baca. 


\section{c. Buku Panduan Kegiatan Kreatif Mandiri}

Buku ini berisi kegiatan menebalkan huruf hijaiyah yang tergabung dalam sebuah gambar alam. Anak diminta untuk menemukan huruf hijaiyah tersebut, kemudian menebalkan. Setelah huruf ditebalkan gambar keseluruhan dapat diberi warna sesuai keinginan anak. Di akhir kegiatan terdapat tugas menebalkan huruf hiyaiyah dan menuliskan huruf hijaiyah sesuai contoh.

d. CD Panduan pembelajaran Bahasa Arab untuk guru TK

CD ini berisi 14 lagu terjemahan lagu anak-anak Indonesia yang berbahasa Arab. Nada yang digunakan sama dengan nada lagu asli, sehingga anak cenderung mudah ntuk menirukan dan menghafal karena lagu tersebut.

2. Bahan Ajar Bahasa Arab untuk Anak usia Dini menurut perspektif Carl Rogers

Carl Rogers berpendapat bahwa belajar memiliki dua tipe, yaitu belajar kognitif dan pengalaman belajar. Belajar kognitif menunjuk kepada jenis-jenis proses assosiasi yang dilambangkan semua teori psikologi belajar tradisional ,termasuk beberapa aspek dari teori kognitif. Sedangkan pengalaman belajar secara manusiawi sangat berarti dan secara emosional relevan dengan teori kognitif.

Salah satu Teori Psikologi Kognitif yang digunakan dan diterjemahkan menjadi dasar pembelajaran bagi anak usia dini ialah teori perkembanga kognitif Piaget. Berikut merupakan kesimpulan peneliti terhadap sumber-sumber belajar tersebut berdasarkan tahapan usia anak :

\section{a. Periode sensorimotor (usia 0-2 tahun)}

Materi ajar yang sesuai untuk mengenalkan bahasa Arab usia ini diantaranya ebook Haza, Hazihi, dan lagu model bahasa Arab. Namun penggunaan e-book Haẓa dan Hazihi dalam pembelajaran, tidak semua materi dalam buku dapat diajarkan bagi anak usia 0-2 tahun. Materi yang dapat diajarkan bagi anak usia usia 0-2 tahun berupa pengenalan gambar berikut nama-namanya dalam bahasa Arab.

Anak usia kurang dari dua tahun merupakan masa perkembangan fisik motorik. Pembelajaran anak usia ini difokuskaan pada perkembangan motorik baik motorik kasar maupun motorik halus. Sistem pembelajaran bahasa asing yang tepat bagi anak usia ini menggunakan metode langsung. E-book Haza dan Hazihi dapat digunakan sebagai bahan belajar bagi anak usia dini dengan cara mengajarkan kemahiran kalam dan istima'. Lingkungan dan pengalaman belajar dapat dibentuk menggunakan dasar E-book Haza dan Haẓihi. Dengan cara mengajarkan materi-materi yang ada dalam buku ini secara langsung dan menjadikan pembiasaan dalam kegiatan sehari-hari. 
b. Periode praoperasional (usia 2-7 tahun)

Sumber belajar yang dapat digunakan bagi anak usia ini diantaranya : e-book Haza dan Hazihi, buku kkm dan lagu model bahasa Arab. Anak usia 2 tahun mulai menyukai warna dan gambar-gambar, kemampuan motorik halus anak usia 2 tahun sudah mulai berkembang. Anak usia ini sudah bisa belajar menggunakan pensil sekedar membuat garis atau coretan. Sehingga e-book Haza dan Hazihi dan lagu model bahasa Arab berfungsi sebagai bahan pembentuk lingkungan berbahasa Arab dan pengalaman belajar.

Lagu model bahasa arab dapat diterapkan pada anak usia 2 tahun dan seterusnya. Nada lagu model bahasa Arab dibuat sama persis dengan lagu asli sebagai contoh lagu sebagai lagu gubahan balonku ada lima memiliki nada yang sama dengan lagu balonku ada lima. Karakter nada yang sama memungkinkan siswa untuk menyatukan informasi dan gagasan baru sebagai bagian dari dirinya.

Buku Kegiatan Kreatif Mandiri dapat diterapkan setelah anak berusia 4 tahun, karena motorik halus anak pada usia ini telah berkembang dengan baik. Disisi lain, anak usia ini mulai menyukai kegiatan menggambar dan mewarnai. Buku kegiatan kreatif mandiri meningkatkan rasa tanggung jawab dan partisipasi siswa. Pembelajaran dasar bahasa Arab menggunakan buku ini meminta anak untuk aktif mencari huruf hijaiyah yang tersembunyi dalam gambar. Selain itu kegiatan mewarnai memberikan kesempatan siswa untuk mengambil keputusan sebagai bagian penting pengalaman belajar menurut Carl rogers.

Analisa Materi- materi ajar bahasa Arab menurut Carl Rogers

a. e-book Haẓa dan Hazihi

E-book Haẓa dan Hazihi berisi pengalaman-pengalaman yang memungkinkan siswa untuk menyatukan informasi dan gagasan baru sebagai bagian dari dirinya. Dalam e-book Haza dan Hazihi materi ajar memadukan antara isim isyarah dengan kosakata. Gagasan-gagasan baru ditemukan pada setiap halaman karena pelajaran dari satu halamn dengan halaman lainnya berbeda. Sedang dalam buku Hazihi penambahan materi berupa pengenalan ta' marbuthoh sebagai identitas kalimat mu'annats. Pembelajaran ini menngenalkan anak kepada jenis kelamin dan kaitanya dengan kata dalam bahasa Arab. Anak diajak untuk menyatukan informasi dan gagasan baru yang ditemukan. 
Self critism" dan "self-evaluation" dalam e-book Haza dan Hazihi berupa pengayaan dengan cara menjawab pertanyaan-pertanyaan dari kegiatan-kegiatan belajar yang telah dilakukan sebelumnya. Kelemahan pada e-book Haza dan Hazihi ialah tidak adanya peluang bagi anak untuk turut berpartisipasi dalam menentukan kegiatan pembelajaran.

b. Buku Kegiatan Kreatifitas mandiri

Pengalaman belajar yang terbentuk dari buku kegiatan kreatif Mandiri diantaranya mengenal dan menyamakan bentuk huruf hijaiyah dengan alam atau benda di sekitar anak. Anak diajak terlibat aktif dalam kegiatan belajar melalui kegiatan menemukan huruf, mewarnai dan menebalkan huruf hijaiyah. Anak diajak untuk berfikir kreatif dan bertanggung jawab menyelesaikan masalah. Kelemahan pada e-book Haza dan Hazihi ialah tidak adanya peluang bagi anak untuk turut berpartisipasi dalam menentukan kegiatan pembelajaran. Kelemahan pada e-book Haz̧a dan Hazihi ialah tidak adanya peluang bagi anak untuk turut berpartisipasi dalam menentukan kegiatan pembelajaran.

c. Lagu Model Bahasa Arab bagi anak Usia Dini

Lagu model bahasa Arab mengajarkan lagu-lagu terjemahan bahasa Arab. Pengalaman belajar yang terbentuk melalui kegiatan bernyanyi. Karakter nada yang sama memungkinkan siswa untuk menyatukan informasi dan gagasan baru sebagai bagian dari dirinya. Pembelajaran menggunakan lagu cenderung menyenangkan bagi anak. Anak memadukan informasi antara pengalaman belajar menggunaan lagu bahasa Indonesia yang telah familiar dengan lagu gubahan bahasa Arab dengan nada yang sama. Kegiatan ini cenderung memudahkan anak dalam belajar, sebelumnya anak telah familiar dengan lagu-lagu yang terdapat dalam lagu model bahasa Arab untuk anak usia dini. 


\section{DAFTAR PUSTAKA}

Abdurrahman dan Rohmani Nur Indah, Psikolinguistik: Konsep dan Isu, Malang: UIN Malang Press, 2008.

Aisyah, Siti, Pembelajaran Terpadu, vol 1, Jakarta: Universitas Terbuka, 2011.

Arifuddin, Neuropsikolinguistik, Jakarta: Rajawali Press, 2010.

Arikunto, Suharsimi, prosedur Penelitian Suatu Pendekatan Praktik, vol.VI, Jakarta, Adi Mahasatya, 2006.

Asrori Imam, Aneka Permainan: Penyegar Pembelajaran Bahasa Arab, Surabaya: Hilal pustaka, 2008 .

Broto, A. S., Pengajaran Bahasa Indonesia Sebagai Bahasa Kedua di Sekolah Dasar Berdasarkan Pendekatan Linguistik Konstransitif, Jakarta: Bulan Bintang, 2000.

Brown, H. Douglas, Prinsip Pembelajaran dan Pengajaran Bahasa, vol. 5, Terj. Noor Cholis \& Yusi Avianto Pareanom, US: Pearson education: 2008.

Chaer, Abdul, Psikolinguistik, Kajian Teoretik, Jakarta: Rineka Cipta, 2002.

Chomsky, N, Aspect Of The Theory Of Syntax, Cambridge: M.I.T. Press, 1965

Dahlan, Juwariyah, Metode Belajar Mengajar Bahasa Arab, Surabaya: Al Ikhlas, 1992.

Dardjowidjojo, Soenjono, Psikolinguistik: Pengantar Pemahaman Bahasa Manusia, Jakarta: Yayasan Obor Indonesia, 2010.

Effendy, Ahmad Fuad, Metodologi Pembelajaran Bahasa Arab, Malang: Misykat, 2008.

Freire, Paulo, Pendidikan Sebagai Proses, Yogyakarta: Pustaka Pelajar, 2000.

Hasan, Maimunah, Pendidikan Anak Usia Dini,Yogyakarta : Diva Press, 2012.

Hamid, Abdul, Psikolinguistik Pembelajaran Bahasa Arab, terj. Jailani Musni, Bandung: Humaniora, 2009.

Hamid, Abdul, dkk, Pembelajaran Bahasa Arab; Pendekatan, Metode, Strategi, Materi, dan Media, Malang: UIN Malang Press, 2008.

Izzaty, Rita, Eka,dkk, Perkembangan Peserta Didik, Yogyakarta:UNY Press, 2008. 
Moleong, Lexy J., Metodologi Penelitian Kualitatif, Bandung: Rosda Karya, 2004.

Montessori, The Science Behind the Genius, Oxford University Press, 2008.

Muhadjir, Noeng, Metodologi Penelitian Kualitatif,vol. 3, Yogyakarta: Rake Sarasin, 2000.

Mutiah, Diana, Psikologi Bermain Anak Usia Din, Yogyakarta: Diva Press, 2010.

Nasution, S., Metode Penelitian Naturalistik Kualitatif, Bandung: Tarsito, 2003.

Nuha, Ulin, Metodologi Super Efektif Pembelajaran Bahasa Arab, Yogyakarta:Diva Press, 2012.

Palmer, Joy A., 50 Pemikir Pendidikan: dari Piaget sampai masa sekarang, Yogyakarta: Jendela, 2003.

Patmonodewo, Soemiarti, Pendidikan Anak Usia Praasekolah, Jakarta: Rineka Cipta Cet. II, 2003.

Peraturan Menteri Pendidikan Nasional republik Indonesia No. 58 Tahun 2009.

Seefeldt, Carol, Pendidikan Anak Usia Dini, Jakarta: Indeks, 2008.

Sembodo, Wawan Wuntat, Menulis dan Mewarnai Huuruf Hijaiyah, Yogyakarta: Pustaka Syahida, 2008.

Shihab, Alwi, Kuliah Umum Universitas Al-Azhar, Peran Bahasa Arab Sebagi Bahasa International dan Bahasa Diplomasi, 27 Desember 2007.

Sudjana, Nana, Teori-teori Belajar untuk Pengajaran, Jakarta: FEUI, 1989.

Solehudin, Pembaharuan Pendidikan TK, Jakarta: Universitas Terbuka,2011.

Sudjana, Nana dan Ibrahim, Penelitian dan Penilaian Pendidikan, Bandung, Sinar Baru Algesindo, 2007.

Sujiono, Bambang, Metode pengembangan fisik, Jakarta: Universitas Terbuka, 2009.

Surasman, O, Yuk, Belajar Harakat Panjang dalam Al-Qur'an: Seri Stiker, Depok: Al-Bayan, 2008 .

Syakur, Nazri, Proses Psikologik dalam Pemerolehan dan Belajar Bahasa: Seri Psikolinguistik, Yogyakarta: Sukses Offset, 2008.

Tarigan, Henry Guntur, Membaca Sebagai Suatu Keterampilan Berbahasa, Bandung: Angkasa, Cet. VII, 1979.

--------------, Pengajaran Kompetensi Bahasa, Bandung: Angkasa, 1984. , Psikolinguistik, Bandung: Angkasa, 1984.

Ubaedy, Cerdas Mengasuh Anak, Jakarta: Kinza Books, 2009.

Yudha, Andi, Kenapa Guru Harus Kreatif, Bandung: Mizan, 2009.

Liu, Zhiliang, Age Effects in Foreign Learning for Children in China, vol.2 No.1, China: CCSE, 2009.

http://m.beritajatim.com/kebijakanpaud/ketua_Fraksi_PDIP_Siswa_TJ_PAUD_jangan_Dipaksa

Berhitung.htm. 
http://id.scribd.com/doc/28689986/Al-Arabiyyatul-Uulaa.

Cameron, Lynne, Teaching Language to Young Learners, United Kingdom, Cambridge University Press, 2001.

Goh, Christine C.M. and Silver, Rita Elaine, Language Acquisition and Development, Singapure: Longman, 2004. 